\title{
BELANJA KEMENTERIAN/LEMBAGA, BELANJA APBD, KONTRIBUSI SEKTORAL, DAN KETIMPANGAN PENDAPATAN DI JAWA TIMUR
}

Ferry Sutiono dan Wildan Syafitri

Universitas Brawijaya

Alamat Korespondensi: fe.ferry@gmail.com

\section{INFORMASI ARTIKEL}

Diterima Pertama

07 Juni 2018

Dinyatakan Diterima

06 Desember 2018

KATA KUNCI:

ketimpangan pendapatan, pengeluaran pemerintah, belanja modal pemerintah, sektor ekonomi

KLASIFIKASI JEL:

H540,0150

\begin{abstract}
ABSTRAK
The high income inequality in East Java is one of the economic problems that the government has to solve as a function of distribution and stabilization. Effective fiscal policy instruments, through the expenditure of Ministries / Agencies and regional expenditures, are expected to decrease the revenue gap in the regions. Government capital expenditure becomes a special instrument because the characteristics of the goods obtained can provide long-term benefits.

The purpose of this study is to determine the effect of capital expenditures of Ministries / Agencies, local government capital expenditures, and contribution of the three main economic sectors to income inequality in East Java. The method of analysis used is panel data regression model by taking population of 38 regencies / cities in East Java Province in the period 2010-2015.

The results show that capital expenditure of Ministries/ Agencies tends to decrease income inequality, while local goverment capital expenditure tends to increase income inequality. The development of the agricultural sector has no significant effect on income inequality. The development of the industrial sector tends to decrease income inequality, and the development of the trade sector tends to increase income inequality.
\end{abstract}

Ketimpangan pendapatan yang tinggi di Jawa Timur adalah salah satu masalah ekonomi yang harus dipecahkan oleh pemerintah sebagai fungsi distribusi maupun stabilisasi. Instrumen kebijakan fiskal yang efektif, melalui belanja Kementerian/Lembaga maupun belanja daerah, diharapkan dapat menurunkan kertimpangan pendapatan di daerah. Belanja modal pemerintah menjadi instrumen yang spesial karena karakteristik barang yang diperoleh bisa memberikan manfaat dalam jangka panjang.

Tujuan penelitian ini adalah untuk mengetahui pengaruh belanja modal Kementerian/ Lembaga, belanja modal APBD, serta kontribusi sektor ekonomi utama pada ketimpangan pendapatan di Jawa Timur. Metode analisis yang digunakan adalah model regresi data panel pada populasi 38 Kabupaten/Kota di Provinsi Jawa Timur dalam kurun waktu 2010-2015.

Hasil penelitian menunjukkan bahwa belanja modal K/L cenderung mengurangi ketimpangan pendapatan, sedangkan belanja modal APBD cenderung meningkatkan ketimpangan pendapatan. Perkembangan sektor pertanian tidak berpengaruh signifikan terhadap ketimpangan pendapatan, sedangkan perkembangan sektor industri cenderung menurunkan ketimpangan pendapatan, dan perkembangan sektor perdagangan cenderung meningkatkan ketimpangan pendapatan. 


\section{PENDAHULUAN}

\subsection{Latar Belakang}

Tingkat ketimpangan pendapatan menjadi salah satu variabel yang mencerminkan ukuran pemerataan kesejahteraan apakah berlaku umum atau hanya dinikmati oleh sebagian masyarakat saja. Pertumbuhan ekonomi yang tinggi belum tentu menjamin kesejahteraan seluruh lapisan masyarakatnya. Hasil dari pertumbuhan ekonomi yang tinggi bisa jadi hanya dinikmati oleh sebagian kecil masyarakat tertentu.

Pada tahun 2017, rata-rata ketimpangan pendapatan di Indonesia cukup tinggi yaitu mencapai angka 0,391 pada ukuran indeks gini. Dari 34 provinsi yang ada di Indonesia, terdapat 9 provinsi yang memiliki angka ketimpangan di atas rata-rata nasional. Fenomena menarik terjadi di Jawa Timur sebagaimana dapat dilihat dalam gambar 1 .

\section{Gambar 1 : Indeks Gini Indonesia dan 9} Provinsi Tertinggi 2017

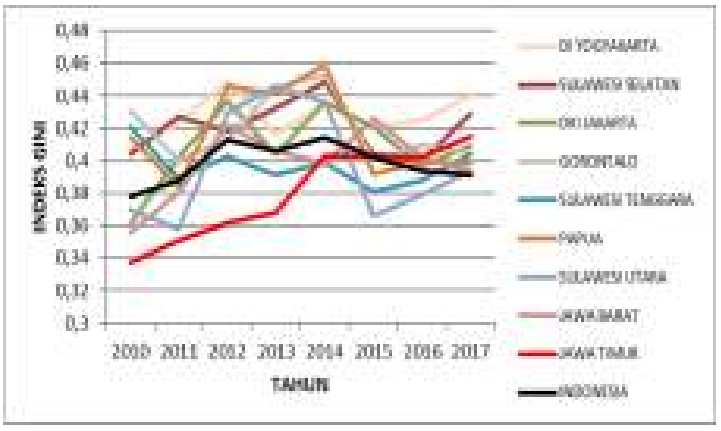

Sumber: Data Diolah BPS, 2018

Angka ketimpangan Jawa Timur dari tahun ke tahun terus naik hingga akhirnya berada di atas angka indeks gini nasional sejak tahun 2015, dan pada tahun 2017 menempati urutan ketiga provinsi dengan angka ketimpangan pendapatan terbesar di Indonesia. Hal tersebut menjadi tantangan bagi pemerintah pusat dan pemerintah daerah di wilayah Jawa Timur yang mana di satu sisi harus tetap menjaga tingkat pertumbuhan ekonomi, sementara di sisi lain juga dituntut untuk menurunkan tingkat ketimpangan demi kesejahteraan masyarakatnya.

Dalam menjalankan aktivitasnya, pemerintah menggunakan instrumen belanja yang tertuang dalam APBN dan APBD untuk mendanai semua kegiatannya. Sebagian dari belanja pemerintah tersebut dialokasikan dalam pos belanja modal. Belanja modal pemerintah merupakan permintaan atas output perekonomian dalam rangka pembentukan aset yang dapat memberikan manfaat lebih dari satu periode anggaran. Oleh karena itu belanja modal menjadi investasi pemerintah pada sektor publik yang sangat penting untuk mendorong perekonomian dan pemerataan pendapatan karena dapat memberikan manfaat dalam jangka panjang.

Perekonomian Jawa Timur telah berkembang cukup pesat dari tahun ke tahun. Tiga sektor utama penyumbang PDRB di Jawa Timur antara lain sektor pertanian, sektor industri, dan sektor perdagangan. Masing-masing sektor memiliki karakteristik yang berbeda-beda.

Penelitian terdahulu di tingkat regional atau lokal yang meneliti hubungan antara belanja pemerintah dengan ketimpangan pendapatan umumnya menggunakan variabel belanja pemerintah yang merujuk pada belanja pemerintah daerah yang tertuang dalam APBD. Sedangkan fakta yang terjadi di lapangan menunjukkan bahwa pemerintah pusat juga ikut berperan melalui belanja Kementerian/Lembaga (K/L) yang tertuang dalam APBN yang dibelanjakan di tingkat lokal atau regional. Oleh karena itu ruang lingkup belanja pemerintah yang ada dalam suatu wilayah tidak hanya terbatas pada belanja APBD saja, tetapi juga mencakup belanja K/L yang dibelanjakan di daerah.

Berdasarkan pertimbangan di atas maka penulis melakukan pengujian pengaruh belanja modal pemerintah dan kontribusi tiga sektor perekonomian utama terhadap ketimpangan pendapatan di Jawa Timur. Penulis tidak menyertakan variabel belanja bantuan sosial agar pengujian dapat terfokus pada belanja modal pemerintah sebagai salah satu instrumen kebijakan fiskal. Penulis mengambil judul "Belanja Kementerian/Lembaga, Belanja APBD, Kontribusi Sektoral, dan Ketimpangan Pendapatan di Jawa Timur".

\subsection{Rumusan Masalah}

Berdasarkan latar belakang dan motivasi penelitian, maka dapat diidentifikasi permasalahan penelitian sebagai berikut:

1. Bagaimana pengaruh belanja modal $\mathrm{K} / \mathrm{L}$ terhadap ketimpangan pendapatan di Jawa Timur?

2. Bagaimana pengaruh belanja modal APBD terhadap ketimpangan pendapatan di Jawa Timur?

3. Bagaimana pengaruh sektor pertanian terhadap ketimpangan pendapatan di Jawa Timur?

4. Bagaimana pengaruh sektor industri terhadap ketimpangan pendapatan di Jawa Timur?

5. Bagaimana pengaruh sektor perdagangan terhadap ketimpangan pendapatan di Jawa Timur?

\subsection{Tujuan Penelitian}

Berdasarkan rumusan masalah di atas, maka tujuan penelitian diuraikan sebagai berikut: 
1. Untuk mengetahui pengaruh belanja modal K/L terhadap ketimpangan pendapatan di Jawa Timur;

2. Untuk mengetahui pengaruh belanja modal APBD terhadap ketimpangan pendapatan di Jawa Timur;

3. Untuk mengetahui pengaruh sektor pertanian terhadap ketimpangan pendapatan di Jawa Timur;

4. Untuk mengetahui pengaruh sektor industri terhadap ketimpangan pendapatan di Jawa Timur;

5. Untuk mengetahui pengaruh sektor perdagangan terhadap ketimpangan pendapatan di Jawa Timur.

\subsection{Manfaat Penelitian}

Hasil penelitian ini diharapkan dapat memberikan manfaat sebagai berikut:

\section{a. Bagi Pemerintah Pusat dan Pemerintah Daerah}

Untuk bahan wacana terhadap kondisi yang dideskripsikan dalam penelitian ini serta sebagai bahan pertimbangan penyusunan kebijakan di masa yang akan datang.

\section{b. Bagi Dunia Pendidikan}

Untuk tambahan referensi serta sebagai kontribusi dalam pelaksanaan penelitianpenelitian serupa di masa yang akan datang.

\subsection{Hipotesis}

1. Diduga belanja modal K/L berpengaruh negatif dan signifikan terhadap ketimpangan pendapatan;

2. Diduga belanja modal APBD berpengaruh negatif dan signifikan terhadap ketimpangan pendapatan.

3. Diduga PDRB sektor pertanian berpengaruh negatif dan signifikan terhadap ketimpangan pendapatan.

4. Diduga PDRB sektor industri berpengaruh negatif dan signifikan terhadap ketimpangan pendapatan.

5. Diduga PDRB sektor perdagangan berpengaruh negatif dan signifikan terhadap ketimpangan pendapatan.

\section{KERANGKA TEORI DAN PENGEMBANGAN HIPOTESIS}

Desentralisasi fiskal menimbulkan pengelolaan keuangan yang terpisah antara pemerintah pusat dan perintah daerah. Peran belanja pemerintah dalam perekonomian dapat dijelaskan melalui Fungsi Pendapatan Nasional yang dikemukakan oleh Keyness. Sedangkan peran kapital atau modal dalam perekonomian dapat dijelaskan melalui Model Pertumbuhan Sollow. Sementara itu, adanya ketimpangan pendapatan dalam ekonomi regional dapat dijelaskan melalui Teori Penyebab Kumulatif yang dikemukakan Profesor Gunnar Myrdal. Dan kontribusi sektoral dapat dijelaskan melalui teori Kuznets.

\subsection{Desentralisasi Fiskal}

Desentralisasi fiskal menimbulkan pengelolaan keuangan yang terpisah antara pemerintah pusat dan perintah daerah. Desentralisasi fiskal diharapkan mampu memberikan peluang yang lebih besar bagi setiap daerah untuk melaksanakan aktivitas pembangunan sesuai dengan potensi dan kebutuhan dari daerah tersebut. Khusaini (2006:46, dalam Hakim, 2014) mengemukakan bahwa pengeluaran publik terutama penyediaan infrastruktur bagi masyarakat akan lebih efektif dilakukan oleh pemerintah daerah (sub-national government) daripada oleh pemerintah pusat karena mereka akan lebih mengetahui apa yang menjadi keinginan dan kebutuhan masyarakat lokal.

\subsection{Pengeluaran Pemerintah dan Belanja Modal}

Peran belanja pemerintah dalam perekonomian dapat dijelaskan melalui Fungsi Pendapatan Nasional yang dikemukakan oleh Keyness. Belanja pemerintah merupakan salah satu komponen pembentuk produk domestik bruto (PDB) suatu negara, atau produk domestik regional bruto (PDRB) suatu wilayah. Belanja pemerintah tidak menyertakan komponen pembayaran transfer karena tidak terdapat pertukaran dengan sebagian output barang dan jasa perekonomian.

Sebagai salah satu komponen pengeluaran, belanja pemerintah yang lebih tinggi mengakibatkan pengeluaran yang direncanakan yang lebih tinggi untuk semua tingkat pendapatan (Mankiw, 2007). Dari gambar 2 dapat dilihat bahwa kenaikan belanja pemerintah dari G1 ke G2 atau sebesar $\Delta \mathrm{G}$ akan meningkatkan pengeluaran yang direncanakan sebesar jumlah itu untuk semua tingkat pendapatan. Ekuilibrium bergerak dari titik A ke titik B, dan pendapatan meningkat dari Y1 ke Y2 atau sebesar $\Delta \mathrm{Y}$. Jadi kenaikan belanja pemerintah sebesar $\Delta G$ akan meningkatkan pendapatan sebesar $\Delta \mathrm{Y}$. Dapat kita lihat bahwa kenaikan dalam pendapatan $\Delta \mathrm{Y}$ lebih besar daripada kenaikan belanja pemerintah $\Delta \mathrm{G}$ yang artinya kenaikan belanja pemerintah memiliki dampak pengganda (multiplier effect) terhadap pendapatan. Pengganda belanja pemerintah (government-purchases multiplier) yang merupakan rasio $\Delta \mathrm{Y} / \Delta \mathrm{G}$ mengindikasikan besaran 
peningkatan pendapatan akibat setiap poin kenaikan belanja pemerintah.

\section{Gambar 2 : Kenaikan Belanja Pemerintah dalam Perpotongan Keynesian}

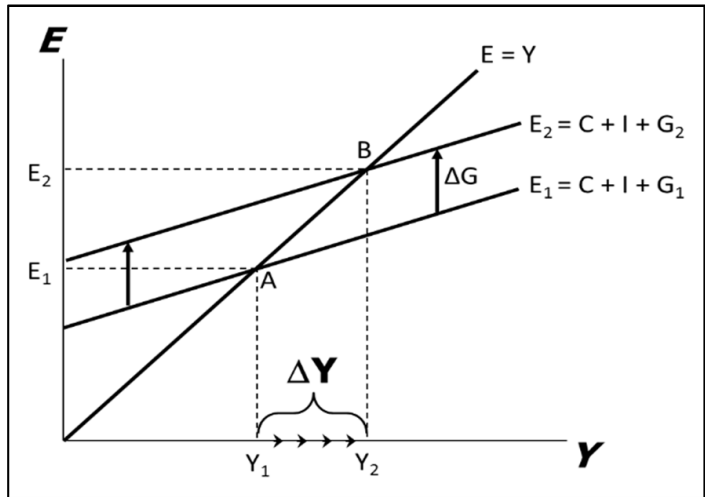

Sumber: Mankiw, 2007

Pengeluaran pemerintah secara umum dapat diklasifikasikan dalam tiga kelompok besar yaitu (i) pengeluaran pemerintah untuk belanja barang dan jasa, (ii) pengeluaran pemerintah untuk pembayaran gaji pegawai, dan (iii) pengeluaran pemerintah untuk pembayaran transfer payment. Belanja modal merupakan salah satu jenis pengeluaran pemerintah yang termasuk dalam klasifikasi belanja barang dan jasa. Belanja modal digunakan untuk perolehan aset tetap dan aset lainnya yang memiliki manfaat lebih dari satu periode anggaran. Output dari belanja modal adalah perolehan aset yang dapat memberikan manfaat melebihi satu periode akuntansi sehingga pada umumnya dapat digunakan dalam jangka panjang sesuai masa manfaat ekonomis aktiva tersebut.

\subsection{PDRB dan Teori Pertumbuhan Ekonomi}

Produk Domestik Regional Bruto (PDRB) merupakan nilai tambah bruto seluruh barang dan jasa yang tercipta atau dihasilkan di wilayah domestik suatu negara yang timbul akibat berbagai aktivitas ekonomi dalam suatu periode tertentu tanpa memperhatikan apakah faktor produksi yang dimiliki residen atau non residen (BPS, 2017). PDRB menjadi indikator penting dalam menilai kinerja ekonomi suatu daerah pada periode tertentu. Perekonomian suatu wilayah dikatakan tumbuh dan berkembang jika produksi barang dan jasa pada suatu periode lebih besar daripada periode sebelumnya.

Peran kapital atau modal dalam perekonomian dapat dijelaskan melalui Model Pertumbuhan Sollow. Tingkat tabungan yang tinggi akan memberikan persediaan modal yang besar bagi perekonomian sehingga dapat mendorong tingkat output yang tinggi pula. Dalam jangka panjang, perekonomian akan menuju pada ekuilibrium perekonomian jangka panjang yang disebut kondisi mapan (steady state) sebagaimana tercermin dalam gambar 3 .

\section{Gambar 3 : Investasi, Depresiasi, dan Kondisi Mapan}

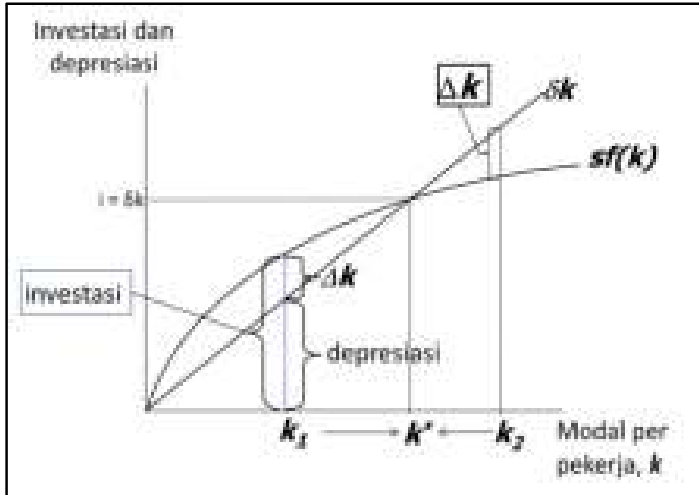

Sumber: Mankiw, 2007

Kondisi mapan $\mathrm{k}^{*}$ tercapai saat perubahan persediaan modal $\Delta \mathrm{k}$ mencapai titik keseimbangan $(\Delta \mathrm{k}=0)$, yang terjadi ketika investasi $\mathrm{sf}(\mathrm{k})$ sama dengan depresiasi $\delta \mathrm{k}$. Apabila investasi melebihi depresiasi, terdapat tambahan modal per pekerja sebesar $\Delta \mathrm{k}$ sehingga persediaan modal akan tumbuh sehingga menggeser kondisi k1 menuju kondisi mapan $\mathrm{k}^{*}$. Begitu pula sebaliknya saat depresiasi melebihi investasi, persediaan modal dari k2 akan menyusut hingga dalam jangka panjang berada dalam titik keseimbangan pada kondisi mapan $\mathrm{k}^{*}$. Tabungan yang lebih tinggi akan mendorong perekonomian tumbuh lebih cepat, tetapi hanya sementara sampai perekonomian mencapai titik keseimbangan baru.

\subsection{Ketimpangan Pendapatan dan Teori Ekonomi Regional}

Tingkat ketimpangan pendapatan dapat mencerminkan ukuran pemerataan kesejahteraan dalam masyarakat. Pembangunan ekonomi yang tercermin dalam pertumbuhan ekonomi, pendapatan nasional, atau pendapatan per kapita tidak dapat menggambarkan kesejahteraan riil dari masyarakat khususnya masyarakat lapisan bawah. Pemerataan ekonomi dapat tercapai dalam kondisi hasil dari pembangunan ekonomi terdistribusi secara merata dan adil.

Ketimpangan pendapatan dalam ekonomi regional dapat dijelaskan melalui Teori Penyebab Kumulatif yang dikemukakan Profesor Gunnar Myrdal. Profesor Gunnar Myrdal melalui Teori Penyebab Kumulatif (Cumulative Causation Theory) berpendapat bahwa sebab utama ketimpangan regional adalah kuatnya dampak balik (backwash effects) dan lemahnya dampak sebar (spread effects). Dampak balik adalah semua perubahan yang bersifat merugikan dari ekspansi ekonomi di suatu tempat karena sebab-sebab di luar tempat itu, yang meliputi dampak migrasi, perpindahan 
modal dan perdagangan serta keseluruhan dampak yang timbul dari proses sebab musabab sirkuler antara faktor-faktor baik nonekonomi maupun ekonomi. Sedangkan dampak sebar merupakan dampak momentum pembangunan yang menyebar secara sentrifugal dari pusat pengembangan ekonomi ke wilayah-wilayah lainnya (Jhingan, 2016).

Kurva Lorenz sering kali menjadi alat pengukuran ketimpangan pendapatan dalam suatu wilayah. Kurva Lorenz menggambarkan hubungan kuantitatif aktual antara persentase penerima pendapatan dengan persentase dari total pendapatan diterima dalam satu periode tertentu (Todaro, 2012). Semakin jauh Kurva Lorenz dari garis diagonal (garis pemerataan sempurna) maka semakin lebar tingkat ketimpangan pendapatan. Bentuk dari Kurva Lorez sebagaimana tergambar dalam gambar 4 .

\section{Gambar 4 : Kurva Lorenz}

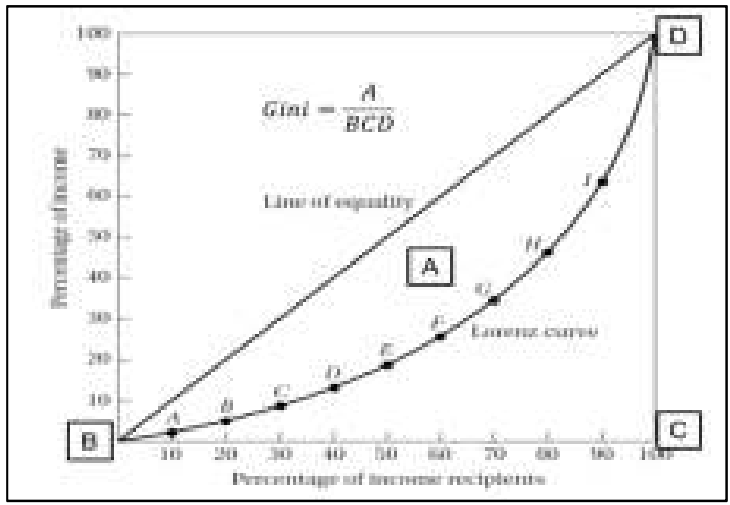

Sumber: Todaro, 2012

Selanjutnya untuk menghitung tingkat ketimpangan suatu wilayah dapat diperoleh dengan menghitung rasio area antara garis diagonal dan Kurva Lorenz (area A yang diarsir) yang dibagi dengan luas setengah persegi dimana Kurva Lorenz berada (area segitiga BCD). Rasio inilah yang disebut dengan indeks gini. Nilai indeks gini yang dihasilkan berkisar antara 0 yang mencerminkan pemerataan sempurna dan 1 yang mencerminkan ketidakmerataan sempurna. Semakin tinggi nilai indeks gini semakin lebar pula ketimpangan pendapatan, sebaliknya semakin rendah nilai indeks gini mencerminkan distribusi pendapatan yang semakin merata.

\subsection{Hubungan antara Belanja Modal dengan Ketimpangan Pendapatan}

Belanja modal pemerintah merupakan pembelian sebagian output perekonomian. Pembelian tersebut menjadikan belanja modal sebagai konsumsi pemerintah yang mencerminkan permintaan atas barang modal. Selanjutnya permintaan dalam perekonomian direspon oleh produsen dengan memproduksi barang modal yang diinginkan sehingga dapat memberikan keuntungan bagi produsen dan dapat pula memberikan upah bagi para pekerja. Pengadaan belanja modal yang bersifat padat karya misalnya pembangunan infrastruktur publik akan menyerap banyak tenaga kerja sehingga memberikan penghasilan bagi para pekerja.

Belanja modal juga merupakan investasi pemerintah karena barang yang diperoleh dapat dimanfaatkan dalam jangka panjang. Apabila barang modal tersebut dimanfaatkan untuk meningkatkan produktivitas, maka balanja modal secara tidak langsung akan berpengaruh terhadap peningkatan produksi dalam jangka panjang pula. Sedangkan untuk output belanja modal dalam bentuk barang publik dapat digunakan untuk mendorong efisiensi produktivitas, perdagangan, dan memperlancar akses pemerataan kesempatan berusaha sehingga dapat meningkatkan pendapatan masyarakat. Dengan peningkatan pendapatan masyarakat diharapkan akan mendorong perekonomian ke arah penciptaan lapangan kerja baru sehingga dapat memberikan penghasilan khususnya bagi masyarakat berpenghasilan rendah. Dengan meningkatnya penghasilan masyarakat maka ketimpangan pendapatan juga akan turun.

\subsection{Hubungan antara PDRB dengan Ketimpangan Pendapatan}

PDRB merupakan indikator penting dalam menghitung kinerja perekonomian suatu daerah. Salah satu kegunaan PDRB adalah untuk menghitung pertumbuhan ekonomi suatu daerah pada periode tertentu yang dibandingkan dengan periode sebelumnya. Oleh sebab itu maka dalam hubungan antara PDRB dengan ketimpangan pendapatan dapat dijelaskan melalui variabel pertumbuhan ekonomi yang mewakili pertumbuhan PDRB suatu wilayah.

Menurut Kuznets dalam Todaro (2012), pada tahap awal pertumbuhan ekonomi, distribusi pendapatan akan cenderung memburuk dan akan membaik pada tahapan selanjutnya. Fenomena tersebut digambarkan dengan Kurva "U-terbalik" Kuznets sebagaimana dapat dilihat pada gambar 5 . Menurut Kuznets (1955) ketimpangan akan semakin parah pada tahapan awal pertumbuhan ekonomi karena adanya perubahan struktural dimana pada tahap awal pertumbuhan ekonomi dikonsentrasikan pada sektor industri modern yang kesempatan kerjanya terbatas tetapi memiliki tingkat upah dan produktivitas yang tinggi. Ketimpangan pendapatan akan terus memburuk seiring pergeseran perekonomian dari sektor tradisional menuju sektor industri modern. Gambar 5 : $\quad$ Kurva “U Terbalik" Kuznets 


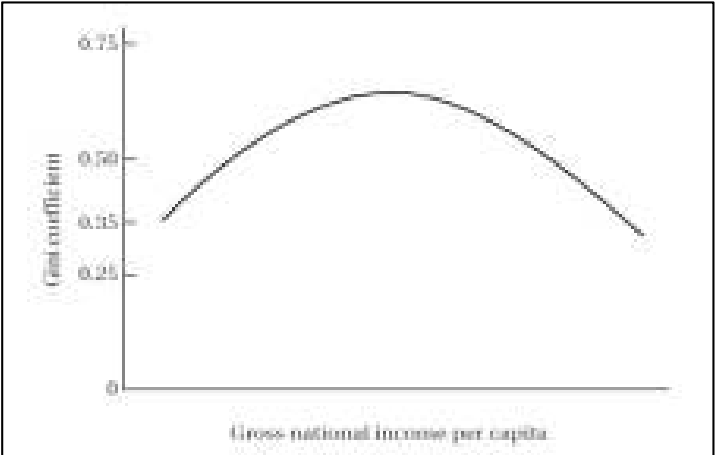

Sumber : Todaro, 2012

Setelah mencapai titik tertentu maka pertumbuhan ekonomi dapat berjalan searah dengan penurunan ketimpangan pendapatan. Titik balik ini dapat terjadi ketika sektor industri di daerah perkotaan sudah mampu menyerap sebagian besar tenaga kerja dari sektor pertanian atau pada saat pangsa pertanian lebih kecil di dalam produksi dan penciptaan pendapatan. Secara tidak langsung Kuznets menganggap bahwa pemerintah seharusnya lebih terfokus pada kebijakan pertumbuhan ekonomi karena ketimpangan pendapatan pada akhirnya tidak dapat dihindari akan naik sampai pada titik tertentu dan kemudian akan turun dengan sendirinya sehingga tidak memerlukan peran pemerintah dalam pemerataan pendapatan.

\subsection{Penelitian Terdahulu}

Beberapa penelitian terdahulu menunjukkan inkonsistensi hasil pengujian antara belanja modal dengan ketimpangan pendapatan. López (2010) dalam tulisannya yang berjudul "Pro-growth, propoor : Is there a trade-off?" mengemukakan bahwa infrastruktur publik merupakan kebijakan yang dapat meningkatkan pertumbuhan sekaligus menurunkan ketimpangan. Sementara itu, Utama (2017) dalam penelitiannya "Pengaruh Kebijakan Fiskal pada Pertumbuhan dan Ketimpangan Ekonomi Indonesia" menyimpulkan bahwa belanja infrastruktur pemerintah Indonesia tidak berpengaruh terhadap pengurangan ketimpangan tetapi berpengaruh terhadap pertumbuhan. Faktor anggaran yang kecil dan pemerataan sebaran menjadi permasalahan. Kondisi infrastruktur yang tertinggal dan terkonsentrasi khususnya di Pulau Jawa sebagai pusat ekonomi, menyebabkan belanja infrastruktur tidak signifikan mengurangi ketimpangan.

Hasil yang berbeda dikemukakan oleh Turnovsky (2015) yang dalam penelitiannya "Economic growth and inequality: The role of public investment" menemukan bahwa belanja pemerintah untuk modal publik akan meningkatkan ketimpangan kesejahteraan dari waktu ke waktu. Investasi pemerintah cenderung meningkatkan produktivitas modal swasta yang pada akhirnya menimbulkan ketimpangan distribusi hasil yang tidak merata antara pemilik modal dengan para buruh. Hasil yang sama diperoleh oleh Sabir (2015) dengan penelitiannya yang berjudul "Local government expenditure, economic growth and income inequality in south sulawesi province" yang menyimpulkan bahwa alokasi belanja modal pada APBD berpengaruh positif dan signifikan terhadap ketimpangan pendapatan. Artinya bahwa peningkatan belanja modal dalam APBD akan meningkatkan ketimpangan pendapatan masyarakat. Hal ini disebabkan alokasi belanja modal lebih banyak digunakan untuk pembangunan infrastruktur di daerah perkotaan dibandingkan alokasi di wilayah pedesaan. Hasil ini sejalan pula dengan penelitian Hur (2014) dalam tulisannya berjudul "Government spending and inclusive growth in developing asia" menyatakan bahwa pengeluaran belanja modal berpengaruh positif terhadap ketimpangan, sehingga diperlukan belanja lain seperti belanja kesehatan dan pendidikan yang cukup untuk mengurangi ketimpangan.

Rubin \& Segal (2015) meneliti hubungan antara pertumbuhan dan ketimpangan pendapatan di AS, dan mendapati hasil bahwa pertumbuhan berkorelasi positif dengan ketimpangan pendapatan. Kesimpulan tersebut kurang lebih sama dengan teori yang dikemukakan Okun (1975) bahwa terdapat tradeoff antara ketimpangan dengan efisiensi. Sementara pengaruh ketimpangan terhadap pertumbuhan dikemukakan oleh Shin (2012) dalam penelitiannya "Income inequality and economic growth" dengan hasil bahwa ketimpangan dapat menghambat pertumbuhan pada tahap awal pembangunan ekonomi, dan dapat mendorong pertumbuhan saat mendekati kondisi mapan. Ivanic (2017) dalam penelitiannya "Sectoral productivity growth and poverty reduction: national and global impacts" menyimpulkan bahwa bahwa di negara-negara miskin, peningkatan produktivitas pertanian pada umumnya memiliki dampak pengurangan kemiskinan yang lebih besar dibandingkan peningkatan pada sektor industri atau jasa.

\subsection{Kerangka Pemikiran}

Gambaran kerangka pemikiran penelitian dapat dilihat pada gambar 6. Desentralisasi fiskal menjadikan pemerintah daerah memilliki kewenangan sendiri dalam menjalankan keuangannya. Keuangan pemerintah daerah dituangkan dalam dokumen APBD yang penggunaannya sepenuhnya menjadi tanggungjawab pemerintah daerah. Jadi dalam pemerintahan di Indonesia terdapat dua struktur utama pemerintah beserta keuanggannya, yaitu pemerintah pusat dengan APBN dan pemerintah daerah dengan APBD. 
Dalam menjalankan aktivitasnya, pemerintah menggunakan instrumen belanja yang tertuang dalam APBN dan APBD untuk mendanai semua kegiatannya. Sebagian dari belanja pemerintah tersebut dialokasikan dalam pos belanja modal. Belanja modal pemerintah merupakan permintaan atas output perekonomian dalam rangka pembentukan aset yang dapat memberikan manfaat lebih dari satu periode anggaran. Oleh karena itu belanja modal menjadi investasi pemerintah pada sektor publik yang sangat penting untuk mendorong perekonomian dan pemerataan pendapatan karena dapat memberikan manfaat dalam jangka panjang.

\section{Gambar 6 : Kerangka Pemikiran}

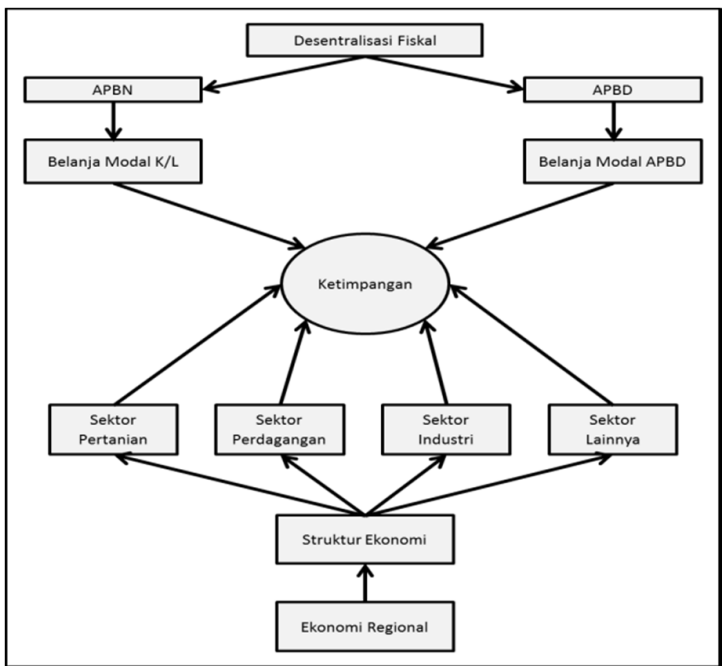

Sumber: Penulis, 2018

Belanja modal pemerintah juga memiliki efek pengganda dalam menggerakkan roda perekonomian. Belanja pemerintah, termasuk belanja modal pemerintah, akan menjadi pendapatan bagi penyedia barang dan jasa, yang selanjutnya akan digunakan untuk konsumsi pada tingkat kedua. Konsumsi tersebut menjadi pendapatan bagi penyedia barang dan jasa pada tingkat kedua dan sebagian akan dikeluarkan lagi sebagai konsumsi pada tingkat ketiga, sehingga menjadi pendapatan bagi penyedia barang dan jasa pada tingkat ketiga, dan seterusnya dengan proses yang berulang-ulang, sehingga memberikan efek pengganda dalam perekonomian. Dan pada akhirnya belanja pemerintah tersebut akan turut meningkatkan PDB secara keseluruhan, atau peningkatan pada PDRB dalam lingkup daerah. Peningkatan dalam perekonomian tersebut dapat mempengaruhi distribusi pendapatan sehingga akhirnya akan berpengaruh pada tingkat pemerataan pendapatan.

Sementara itu, perkembangan perekonomian regional diantaranya akan menimbulkan pergeseran struktur perekonomian dan juga perpindahan tenaga kerja. Seiring dengan pertumbuhan ekonomi, struktur perekonomian akan bergeser dari sektor tradisional seperti sektor pertanian menuju sektor modern seperti sektor industri, yang memberikan tingkat pengembalian yang lebih tinggi. Pergeseran ini akan mempengaruhi komposisi dan sumbangan PDRB menurut lapangan usaha. Sektor usaha modern akan memberikan tingkat pengembalian yang lebih tinggi daripada sektor perekonomian tradisional sehingga akan menimbulkan ketimpangan pendapatan antar sektor. Hasil dari masing-masing sektor dengan karakteristiknya masing-masing dapat mempengaruhi pergerakan pemerataan pendapatan.

\section{METODOLOGI PENELITIAN}

Pendekatan yang digunakan dalam penelitian ini adalah pendekatan deskriptif kuantitatif yang menitikberatkan kepada pengujian hipotesis. Penelitian ini menggunakan data pada 29 Kabupaten dan 9 Kota di Provinsi Jawa Timur pada tahun 2010-2015. Jenis data yang digunakan dalam penelitian ini adalah data sekunder dan data yang digunakan berupa data panel yaitu gabungan antara data cross-section dan data time-series. Data yang digunakan dalam penelitian ini diperoleh dari Direktorat Jenderal Perbendaharaan Negara (DJPb), publikasi data keuangan daerah dari situs Direktorat Jenderal Perimbangan Keuangan (DJPK), dan publikasi dari Badan Pusat Statistik (BPS) serta Badan Pusat Statistik Provinsi Jawa Timur (BPS Jatim).

Metode analisis data yang digunakan dalam penelitian ini adalah model regresi data panel. Penelitian menggunakan variabel rasio terhadap PDRB sebagai variabel bebas, antara lain rasio belanja modal Kementerian/Lembaga (RBMKL), rasio belanja modal APBD (RBMAPBD), rasio PDRB sektor pertanian (RPDRBTAN), rasio PDRB sektor industri (RPDRBIND), dan rasio PDRB sektor perdagangan (RPDRBDAG). Variabel-variabel tersebut akan diregresikan terhadap variabel terikat yaitu ketimpangan pendapatan (GINI) untuk mengetahui pengaruhnya. Penggunaan metode analisis data panel karena data yang dianalisis merupakan gabungan antara data antar waktu (time series) dan data antar individu (crosssection). Pengujian data dilakukan dengan menggunakan apliaksi EViews 9.

Langkah pertama pengujian dengan dengan memilih metode estimasi terbaik diantara tiga pendekatan atau model, yaitu common effect model, fixed effect model, dan random effect model. Pemilihan metode estimasi terbaik menggunakan uji chow dan uji hausman. Setelah diperoleh metode estimasi terbaik, maka pengujian dapat dilakukan untuk memperoleh hasil regresi. Kemudian dilanjutkan dengan melakukan uji 
asumsi klasik antara lain uji normalitas, uji multikolinearitas, uji heteroskedastisitas, dan uji autokorelasi.

Langkah selanjutnya adalah pengujian hipotesis antara lain uji $\mathrm{R}^{2}$, uji-F, dan uji-t. $\mathrm{R}^{2}$ (koefisien determinasi) digunakan untuk mengukur besarnya variasi perubahan variabel dependen yang dijelaskan oleh semua variabel independen. Uji F ini dilakukan untuk menguji signifikansi pengaruh seluruh variabel independen terhadap variabel dependen secara sekaligus tanpa memperhatikan tingkat pengaruh dari setiap variabel. Dan uji-t dilakukan untuk mengetahui apakah variabel-variabel independen yang digunakan dalam persamaan secara parsial mempunyai pengaruh signifikan terhadap variabel dependen.

\section{HASIL PENELITIAN}

\subsection{Gambaran Umum Perekonomian Jawa Timur}

Kinerja makro ekonomi daerah merupakan hasil yang dicapai dari pengelolaan dan manajemen sumberdaya pembangunan yang dimiliki masing-masing daerah bersangkutan (Sabir, 2015). Oleh karena itu hasil kinerja makro ekonomi daerah dapat berbeda-beda antara daerah satu dengan daerah lain tergantung pada sumber daya dan pengelolaannya. Kinerja makro ekonomi daerah tersebut diantaranya tercermin dalam PDRB, stuktur ekonomi dan pendapatan perkapita. Sedangkan gambaran kondisi ketimpangan pendapatan dapat dilihat melalui indeks gini masing-masing kabupaten/kota.

\subsubsection{PDRB Jawa Timur}

PDRB merupakan salah satu indikator dalam menilai kinerja makro ekonomi daerah. Sejak tahun 2011 hingga tahun 2016, perekonomian Jawa Timur selalu memberikan sumbangan lebih dari 14\% terhadap pendapatan domestik bruto (PDB) Indonesia. Tabel 1 menggambarkan pertumbuhan ekonomi provinsi di Pulau Jawa dengan tahun dasar 2010 dan kontribusi Jawa Timur terhadap perekonomian nasional.

PDRB Jawa Timur pada tahun 2016 memberikan kontribusi sebesar 14,65 persen terhadap perekonomian nasional, yang mana angka ini sedikit lebih tinggi dibandingkan tahun 2015 dimana Jawa Timur menyumbang kontribusi sebesar 14,53 persen terhadap perekonomian nasional. Sedangkan laju pertumbuhan ekonomi Jawa Timur cenderung melambat dari yang semula $6,44 \%$ di tahun 2011 menjadi $5,45 \%$ pada tahun 2016.
Tabel 1 : Pertumbuhan Ekonomi dan Kontribusi Jawa Timur

\begin{tabular}{|l|c|c|c|c|c|c|c|}
\hline \multirow{2}{*}{ Provinsi } & \multicolumn{7}{|c|}{ Tahun } \\
\cline { 2 - 9 } & $\mathbf{2 0 1 1}$ & $\mathbf{2 0 1 2}$ & $\mathbf{2 0 1 3}$ & $\mathbf{2 0 1 4}$ & $\mathbf{2 0 1 5}$ & $\mathbf{2 0 1 6}$ & $\mathbf{2 0 1 7}$ \\
\hline Jakarta & 6.73 & 6.53 & 6.07 & 5.91 & 5.91 & 5.88 & 6.22 \\
\hline Jabar & 6.5 & 6.5 & 6.33 & 5.09 & 5.05 & 5.66 & 5.29 \\
\hline Jateng & 5.3 & 5.34 & 5.11 & 5.27 & 5.47 & 5.27 & 5.27 \\
\hline Yogyakarta & 5.21 & 5.37 & 5.47 & 5.17 & 4.95 & 5.05 & 5.26 \\
\hline Jatim & 6.44 & 6.64 & 6.08 & 5.86 & 5.44 & 5.57 & 5.45 \\
\hline Banten & 7.03 & 6.83 & 6.67 & 5.51 & 5.45 & 5.28 & 5.71 \\
\hline Nasional & 6,35 & 6,23 & 5,78 & 5,02 & 4,79 & 5,02 & 5,07 \\
\hline $\begin{array}{l}\text { Kontribusi } \\
\text { Jatim }\end{array}$ & 14.32 & 14.4 & 14.39 & 14.4 & 14.53 & 14.65 & 14.61 \\
\hline
\end{tabular}

Sumber: data diolah BPS, 2018

Perkembangan PDRB menjadi salah satu indikator penting dalam mengukur kondisi dan kinerja pembangunan perekonomian suatu daerah. Untuk melihat perkembangan struktur perekonomian dan kemampuan sumber daya ekonomi yang dihasilkan oleh suatu wilayah digunakan PDRB yang dihitung atas dasar harga berlaku (PDRB ADHB). Secara umum perkembangan nilai PDRB ADHB di Kabupaten/Kota di Provinsi Jawa Timur selama tahun 2010-2016 mengalami kenaikan setiap tahunnya, dengan rata-rata distribusi PDRB kabupaten/kota di Jawa Timur dapat dilihat pada gambar 7.

\section{Gambar 7 : Rata-Rata Distribusi PDRB} Kabupaten/Kota di Jawa Timur 2010-2016

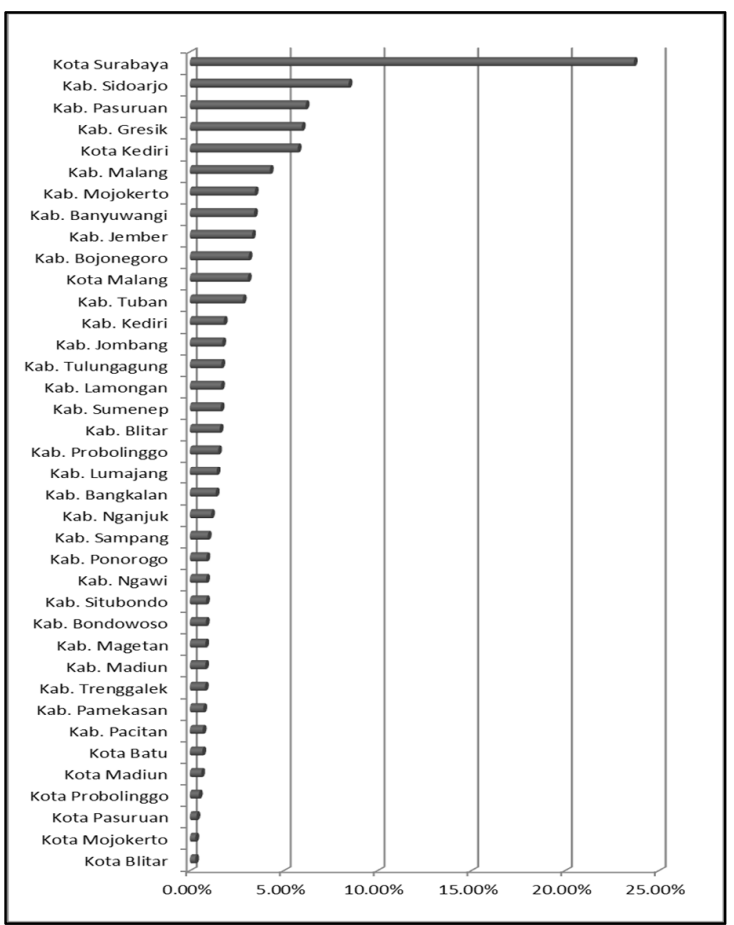

Sumber: Data Diolah BPS Provinsi Jawa Timur, 2018

Komposisi Kabupaten/Kota penyumbang PDRB di Jawa Timur dari tahun ke tahun relatif tidak banyak berubah. Kota Surabaya menjadi penyumbang terbesar dengan rata-rata kontribusi terhadap PDRB Jawa Timur sebesar 23,67\%. Di 
posisi kedua ada Kabupaten Sidoarjo dengan ratarata kontribusi sebesar 8,46\%, disusul kemudian oleh Kabupaten Pasuruan, Kabupaten Gresik, Kota Kediri, Kabupaten Malang, dan Kabupaten Mojokerto. Keseluruhan daerah tersebut merupakan daerah basis industri di Jawa Timur. Sedangkan daerah dengan kontribusi PDRB terendah ditempati daerah perkotaan selain Kota Kediri dan Kota Surabaya, yaitu antara lain terdapat Kota Blitar, Kota Mojokerto, Kota Pasuruan, Kota Probolinggo, Kota Madiun, dan Kota Batu.

\subsubsection{Struktur Ekonomi Jawa Timur}

Perekonomian Jawa Timur pada tahun 2016 sebagian besar berasal dari sektor usaha industri pengolahan dengan kontribusi sebesar 28,92 persen. Sektor usaha perdagangan besar dan eceran, reparasi mobil dan sepeda motor menempati posisi kedua dengan sumbangan sebesar 18 persen. Sedangkan lapangan usaha pertanian, kehutanan dan perikanan menjadi sektor terbesar ketiga dengan kontribusi sebesar 13,31 persen. Secara bersama-sama ketiga lapangan usaha tersebut memberikan kontribusi sebesar 60,23 persen terhadap total PDRB Provinsi Jawa Timur. Untuk mengetahui pergeseran struktur ekonomi dapat dilihat pada gambar 8 berikut ini.

\section{Gambar 8 : Komposisi Struktur Ekonomi Jawa Timur}

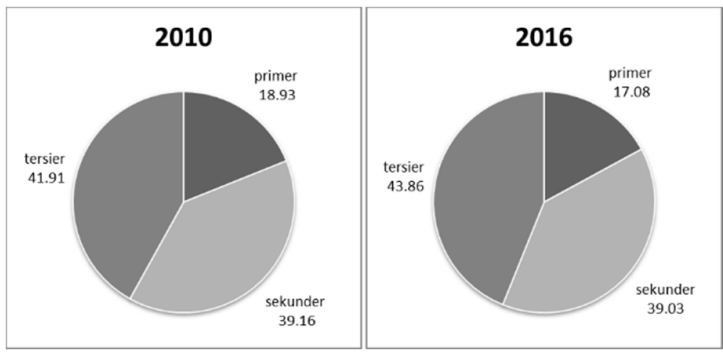

Sumber: Data Diolah BPS Provinsi Jawa Timur, 2017

Berdasarkan gambar di atas, kontribusi sektor usaha sekunder lebih dari dua kali lipat dibandingkan kontribusi sektor usaha primer, baik pada tahun 2010 maupun pada tahun 2016. Perbandingan tersebut mengindikasikan bahwa struktur perekonomian Provinsi Jawa Timur telah bergeser dari sektor primer yang tradisional yaitu pertanian dan pertambangan ke sektor sekunder yang lebih modern yaitu industri pengolahan, pengadaan listrik dan gas, pengadaan air, serta konstruksi. Hal ini sesuai dengan pendapat Kuznets yang memprediksi terjadinya pergeseran perekonomian dari sektor tradisional menuju sektor modern.

Dilihat dari perkembangan per struktur usaha dari tahun 2010 sampai 2016, kontribusi sektor usaha sekunder relatif stabil. Pergeseran terjadi dari sektor usaha primer ke sektor usaha tersier (sektor perdagangan, hotel dan restoran, sektor pengangkutan dan komunikasi, sektor keuangan, persewaan dan perusahaan serta sektor jasa-jasa). Kecendenrungan tersebut ditandai oleh adanya penurunan kontribusi sektor primer dan peningkatan kontribusi sektor tersier. Gambaran tersebut sesuai dengan pendapat Gunnar Myrdal yang mengindikasikan keuntungan yang lebih besar pada sektor tersier sehingga menyedot sumber daya dari sektor primer.

\subsubsection{Pendapatan Perkapita Jawa Timur}

Pendapatan perkapita merupakan salah satu indikator tingkat pembangunan perekonomian dan kemakmuran masyarakat dalam suatu wilayah. Pendapatan perkapita mencerminkan pendapatan rata-rata masyarakat suatu wilayah. Semakin besar pendapatan perkapita maka dapat mengindikasikan semakin makmur pula masyarakat di daerah tersebut. Pendapatan perkapita diperoleh dari hasil pembagian PDRB suatu daerah dengan jumlah penduduk daerah tersebut dalam tahun yang sama, sehingga dapat disebut PDRB perkapita. Gambaran PDRB perkapita kabupaten/kota di Jawa Timur pada tahun 2016 dapat dilihat pada gambar 9.

Gambar 9 : PDRB Perkapita ADHB Kabupaten/Kota Di Jawa Timur Tahun 2016

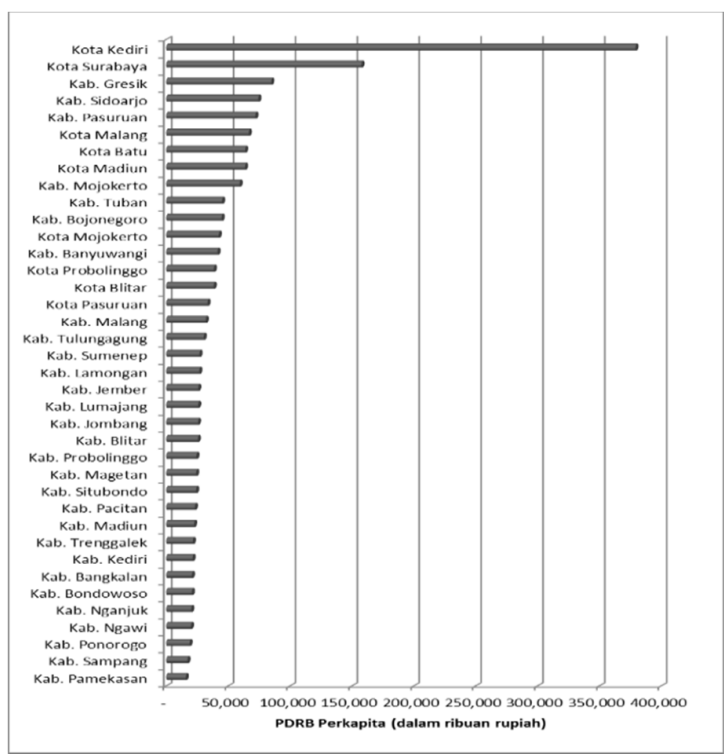

Sumber: Data Diolah BPS Provinsi Jawa Timur, 2018

Pendapatan perkapita Jawa Timur meningkat cukup tinggi dari yang sebelumnya Rp26,37 juta pada tahun 2010 menjadi Rp47,47 juta pada tahun 2016. Terdapat 9 daerah yang memiliki nilai pendapatan perkapita lebih tinggi daripada ratarata provinsi pada tahun 2016, yaitu Kota Kediri, Kota Surabaya, Kabupaten Gresik, Kabupaten 
Sidoarjo, Kabupaten Pasuruan, Kota Malang, Kota Madiun, Kota Batu, dan Kabupaten Mojokerto. Sedangkan 29 daerah lainnya memiliki pendapatan perkapita lebih rendah daripada rata-rata provinsi. Hal ini mengindikasikan adanya ketimpangan perekonomian antar daerah yang cukup tinggi, khususnya Kota Kediri dan Kota Surabaya yang PDRB per kapitanya jauh lebih tinggi daripada daerah-daerah lain.

Kota Kediri memiliki PDRB per kapita tertinggi di Jawa Timur pada tahun 2016 (Rp379 juta) dan bahkan nilainya melebihi dua kali lipat dari PDRB Kota Surabaya (Rp157,7 juta) yang notabene adalah pusat perekonomian di Jawa Timur. Besaran PDRB per kapita Kota Kediri bahkan mencapai 23,95 kali lipat besaran PDRB perkapita Kabupaten Pamekasan (Rp15,8 juta) yang memiliki nilai PDRB per kapita terkecil pada tahun 2016. Fenomena ini terjadi karena PDRB Kota Kediri sebagian besar disumbang oleh sektor industri pengolahan dengan kontribusi 81,64\% pada tahun 2016. Hal ini erat kaitannya dengan keberadaan industri rokok Gudang Garam yang merupakan salah satu pabrik rokok terbesar di Asia Tenggara.

\subsubsection{Indeks Gini Jawa Timur}

Indeks gini dapat memberikan gambaran kondisi pemerataan pendapatan masyarakat dalam suatu daerah pada kurun waktu tertentu. Tabel 2 berikut ini menggambarkan perkembangan indeks gini kabupaten/kota di Jawa Timur tahun 20102015.

\section{Tabel 2 : Indeks Gini Kabupeten/Kota di Jawa Timur Tahun 2010-2015}

\begin{tabular}{|c|c|c|c|c|c|c|}
\hline \multirow{2}{*}{ KAB/KOTA } & \multicolumn{6}{|c|}{ TAHUN } \\
\hline & 2010 & 2011 & 2012 & 2013 & 2014 & 2015 \\
\hline \begin{tabular}{|l|} 
Kab. Bangkalan \\
\end{tabular} & 0,29 & 0,30 & 0,28 & 0,28 & 0,33 & 0,32 \\
\hline Kab. Banyuwangi & 0,24 & 0,32 & 0,29 & 0,30 & 0,29 & 0,34 \\
\hline Kab. Blitar & 0,27 & 0,33 & 0,36 & 0,33 & 0,30 & 0,33 \\
\hline Kab. Bojonegoro & 0,28 & 0,27 & 0,31 & 0,32 & 0,28 & 0,32 \\
\hline Kab. Bondowoso & 0,21 & 0,29 & 0,30 & 0,28 & 0,27 & 0,32 \\
\hline Kab. Gresik & 0,24 & 0,33 & 0,43 & 0,36 & 0,28 & 0,31 \\
\hline Kab. Jember & 0,25 & 0,31 & 0,28 & 0,26 & 0,26 & 0,33 \\
\hline Kab. Jombang & 0,26 & 0,37 & 0,30 & 0,28 & 0,32 & 0,32 \\
\hline Kab. Kediri & 0,26 & 0,31 & 0,32 & 0,30 & 0,31 & 0,34 \\
\hline \begin{tabular}{|l|} 
Kab. Lamongan \\
\end{tabular} & 0,23 & 0,29 & 0,27 & 0,31 & 0,27 & 0,30 \\
\hline Kab. Lumajang & 0,24 & 0,27 & 0,27 & 0,23 & 0,23 & 0,29 \\
\hline \begin{tabular}{|l} 
Kab. Madiun \\
\end{tabular} & 0,25 & 0,29 & 0,34 & 0,30 & 0,28 & 0,32 \\
\hline Kab. Magetan & 0,27 & 0,31 & 0,33 & 0,34 & 0,32 & 0,34 \\
\hline Kab. Malang & 0,30 & 0,33 & 0,32 & 0,38 & 0,33 & 0,38 \\
\hline Kab. Mojokerto & 0,25 & 0,27 & 0,28 & 0,28 & 0,27 & 0,31 \\
\hline \begin{tabular}{|l} 
Kab. Nganjuk \\
\end{tabular} & 0,24 & 0,31 & 0,38 & 0,33 & 0,30 & 0,35 \\
\hline Kab. Ngawi & 0,22 & 0,30 & 0,30 & 0,32 & 0,34 & 0,34 \\
\hline \begin{tabular}{|l|} 
Kab. Pacitan \\
\end{tabular} & 0,29 & 0,34 & 0,31 & 0,33 & 0,31 & 0,33 \\
\hline Kab. Pamekasan & 0,26 & 0,28 & 0,24 & 0,25 & 0,26 & 0,34 \\
\hline \begin{tabular}{|l|} 
Kab. Pasuruan \\
\end{tabular} & 0,26 & 0,28 & 0,30 & 0,28 & 0,28 & 0,32 \\
\hline Kab. Ponorogo & 0,25 & 0,29 & 0,31 & 0,34 & 0,31 & 0,36 \\
\hline Kab. Probolinggo & 0,25 & 0,28 & 0,30 & 0,34 & 0,32 & 0,30 \\
\hline Kab. Sampang & 0,24 & 0,26 & 0,25 & 0,25 & 0,23 & 0,30 \\
\hline Kab. Sidoarjo & 0,27 & 0,31 & 0,33 & 0,30 & 0,30 & 0,35 \\
\hline Kab. Situbondo & 0,26 & 0,26 & 0,27 & 0,28 & 0,29 & 0,33 \\
\hline Kab. Sumenep & 0,27 & 0,27 & 0,30 & 0,29 & 0,25 & 0,26 \\
\hline Kab. Trenggalek & 0,29 & 0,34 & 0,32 & 0,35 & 0,31 & 0,37 \\
\hline Kab. Tuban & 0,25 & 0,28 & 0,27 & 0,30 & 0,24 & 0,29 \\
\hline Kab. Tulungagung & 0,27 & 0,32 & 0,34 & 0,37 & 0,31 & 0,36 \\
\hline \begin{tabular}{|l} 
Kota Batu \\
\end{tabular} & 0,31 & 0,32 & 0,32 & 0,31 & 0,29 & 0,36 \\
\hline \begin{tabular}{|l} 
Kota Blitar \\
\end{tabular} & 0,33 & 0,34 & 0,38 & 0,40 & 0,35 & 0,37 \\
\hline \begin{tabular}{|l} 
Kota Kediri \\
\end{tabular} & 0,28 & 0,39 & 0,39 & 0,33 & 0,31 & 0,40 \\
\hline Kota Madiun & 0,32 & 0,33 & 0,35 & 0,43 & 0,34 & 0,38 \\
\hline \begin{tabular}{|l} 
Kota Malang \\
\end{tabular} & 0,35 & 0,36 & 0,48 & 0,38 & 0,37 & 0,38 \\
\hline Kota Mojokerto & 0,31 & 0,36 & 0,30 & 0,30 & 0,31 & 0,36 \\
\hline \begin{tabular}{|l} 
Kota Pasuruan \\
\end{tabular} & 0,27 & 0,37 & 0,37 & 0,32 & 0,31 & 0,39 \\
\hline Kota Probolinggo & 0,24 & 0,33 & 0,28 & 0,38 & 0,33 & 0,36 \\
\hline Kota Surabaya & 0,36 & 0,37 & 0,40 & 0,37 & 0,39 & 0,42 \\
\hline \begin{tabular}{|l} 
Jawa Timur \\
\end{tabular} & 0,337 & 0,351 & 0,362 & 0,368 & 0,403 & 0,403 \\
\hline
\end{tabular}

Sumber: Data Diolah BPS Provinsi Jawa Timur, 2016

Secara umum perkembangan indeks gini Provinsi Jawa Timur meningkat tajam dalam beberapa tahun terakhir, dari yang awalnya sebesar 0,337 pada tahun 2010 menjadi 0,403 pada tahun 2015. Berdasarkan tabel 2 terdapat beberapa daerah yang pada tahun tertentu sempat mengalami kondisi ketimpangan yang termasuk dalam kategori sedang yaitu dengan nilai indeks gini lebih dari 4. Daerah tersebut antara lain Kabupaten Gresik, Kota Malang, dan Kota Surabaya (2012), Kota Blitar dan Kota Madiun (2013), serta Kota Kediri dan Kota Surabaya (2015). Sedangkan Kabupaten/Kota lainnya termasuk dalam kategori ketimpangan rendah.

\subsection{Hasil Pengujian}

Hasil dari uji chow dan uji hausman samasama memiliki probabilitas yang signifikan sehingga model estimasi terbaik adalah fixed effects model. Regresi data penel dengan menggunakan fixed effects model diperoleh hasil sebagaimana pada tabel 3 berikut ini.

Tabel 3 : Hasil Regresi

\begin{tabular}{|l|r|l|}
\hline \multicolumn{1}{|c|}{ Variable } & Coefficient & Prob. \\
\hline C & 0.280980 & 0.0420 \\
\hline RBMKL & -2.409618 & $0.0162^{* *}$ \\
\hline RBMAPBD & 1.801513 & $0.0015^{* * *}$ \\
\hline RPDRBTAN & -0.274091 & 0.3503 \\
\hline RPDRBIND & -0.898113 & $0.0765^{*}$ \\
\hline RPDRBDAG & 1.515984 & $0.0018^{* * *}$ \\
\hline
\end{tabular}

Keterangan: ${ }^{*} \alpha=0,1 ;{ }^{* *} \alpha=0,05 ;{ }^{* * *} \alpha=0,01$

Sumber: Data Diolah, 2018

Pengujian hipotesis dilakukan untuk memastikan bahwa hasil regresi valid atau memiliki ketepatan dalam estimasi, tidak bias, dan konsisten. Hasil dari uji normalitas menunjukkan bahwa data dalam penelitian ini tidak terdistribusi normal. Hal ini tidak menjadi masalah karena pada dasarnya uji normalitas tidak merupakan syarat BLUE (Best Linier Unbias Estimator).

Pengujian asumsi klasik berikutnya adalah uji multikolinearitas yang menghasilkan kesimpulan tidak terjadi multikolinearitas. Hasil uji heteroskedastisitas tidak signifikan sehingga tidak terjadi heteroskedastisitas. Dan uji autokorelasi menghasilkan nilai yang berada pada daerah bebas autokorelasi sehingga dapat disimpulkan bahwa dalam pengujian ini tidak terdapat autokorelasi. Dengan hasil pengujian asumsi klasik di atas dapat disimpulkan bahwa hasil regresi memenuhi syarat BLUE.

Langkah selanjutnya adalah melakukan pengujian hipotesis. Uji-t dijelaskan bersamaan dengan pembahasan masing-masing variabel di bawah ini. Uji-F memperoleh hasil yang signifikan sehingga dapat dinyatakan bahwa variabel bebas 
secara bersama-sama memberikan pengaruh yang signifikan terhadap variabel terikat. Uji $\mathrm{R}^{2}$ menghasilkan nilai 0,59 yang artinya kemampuan variabel bebas dalam mempengaruhi variabel terikat adalah sebesar 59\%, sedangkan $41 \%$ sisanya dipengaruhi oleh variabel-variabel lain yang tidak termasuk dalam model.

Secara ringkas, hipotesis dan hasil regresi data panel dengan menggunakan fixed effects model dalam penelitian ini dapat dilihat dalam tabel 4 berikut.

Tabel 4 : Hipotesis dan Hasil

\begin{tabular}{|l|l|l|}
\hline Variabel & Hasil & Keterangan \\
\hline $\begin{array}{l}\text { Belanja Modal } \\
\text { K/L }\end{array}$ & $\begin{array}{l}\text { Negatif dan } \\
\text { signifikan }\end{array}$ & $\begin{array}{l}\text { Hasil sesuai } \\
\text { hipotesis }\end{array}$ \\
\hline $\begin{array}{l}\text { Belanja Modal } \\
\text { APBD }\end{array}$ & $\begin{array}{l}\text { Positif dan } \\
\text { signifikan }\end{array}$ & $\begin{array}{l}\text { Hasil tidak } \\
\text { sesuai } \\
\text { hipotesis }\end{array}$ \\
\hline $\begin{array}{l}\text { PDRB Sektor } \\
\text { Pertanian }\end{array}$ & $\begin{array}{l}\text { Negatif dan } \\
\text { tidak } \\
\text { signifikan }\end{array}$ & $\begin{array}{l}\text { Hasil tidak } \\
\text { sesuai } \\
\text { hipotesis }\end{array}$ \\
\hline $\begin{array}{l}\text { PDRB Sektor } \\
\text { Industri }\end{array}$ & $\begin{array}{l}\text { Negatif dan } \\
\text { signifikan }\end{array}$ & $\begin{array}{l}\text { Hasil sesuai } \\
\text { hipotesis }\end{array}$ \\
\hline $\begin{array}{l}\text { PDRB Sektor } \\
\text { Perdagangan }\end{array}$ & $\begin{array}{l}\text { Positif dan } \\
\text { signifikan }\end{array}$ & $\begin{array}{l}\text { Hasil tidak } \\
\text { sesuai } \\
\text { hipotesis }\end{array}$ \\
\hline
\end{tabular}

Sumber: Penulis, 2018

\subsection{Pembahasan}

\subsubsection{Pengaruh Belanja Modal K/L Terhadap Ketimpangan}

Hasil regresi untuk variabel rasio belanja modal $\mathrm{K} / \mathrm{L}$ dalam penelitian ini menghasilkan output berpengaruh negatif dan signifikan terhadap ketimpangan. Artinya bahwa semakin besar rasio belanja modal K/L terhadap PDRB akan memberikan dampak pada penurunan tingkat ketimpangan pendapatan masyarakat sehingga dapat mendukung pemerataan pendapatan.

Penambahan belanja modal K/L dapat mengurangi tingkat ketimpangan apabila menghasilkan rasio terhadap PDRB yang lebih besar dari sebelumnya. Artinya persentase kenaikan belanja modal $\mathrm{K} / \mathrm{L}$ harus melebihi persentase kenaikan PDRB pada tahun yang sama. Jadi variabel belanja modal $\mathrm{K} / \mathrm{L}$ dapat menjadi variabel penyeimbang dalam rangka menciptakan pemerataan ekonomi.

Hasil ini sesuai dengan dugaan awal bahwa belanja modal pemerintah yang dilaksanakan oleh $\mathrm{K} / \mathrm{L}$ berpengaruh negatif terhadap ketimpangan. Belanja modal yang dilakukan oleh $\mathrm{K} / \mathrm{L}$ secara signifikan dapat mengurangi ketimpangan pendapatan dalam masyarakat. Hasil ini tidak sesuai dengan hasil penelitian terdahulu yang dilakukan oleh Hur (2014) dan Turnovsky (2015) yang menghasilkan kesimpulan bahwa pengeluaran belanja modal akan meningkatkan ketimpangan. Dari hasil tersebut terdapat indikasi bahwa efektivitas pelaksanaan anggaran yang dilaksanakan instansi K/L cukup baik sehingga dapat turut berperan dalam pengurangan ketimpangan pendapatan.

\subsubsection{Pengaruh Belanja Modal APBD Terhadap Ketimpangan}

Hasil regresi untuk variabel rasio belanja modal APBD dalam penelitian ini menghasilkan output berpengaruh positif dan signifikan terhadap ketimpangan. Artinya bahwa semakin besar rasio belanja modal APBD terhadap PDRB akan memberikan dampak pada naiknya tingkat ketimpangan pendapatan masyarakat sehingga dapat menghambat pemerataan pendapatan.

Penambahan belanja modal APBD akan dapat menaikkan tingkat ketimpangan apabila menghasilkan rasio terhadap PDRB yang lebih besar dari sebelumnya. Artinya apabila persentase kenaikan belanja modal APBD melebihi persentase kenaikan PDRB pada tahun yang sama maka akan mendorong naiknya ketimpangan pendapatan.

Hasil ini tidak sesuai dengan dugaan awal bahwa belanja modal APBD dapat menurunkan ketimpangan pendapatan. Akan tetapi hasil ini sesuai dengan hasil penelitian terdahulu yang dilakukan oleh Hur (2014) yang menyatakan bahwa pengeluaran belanja modal berpengaruh positif terhadap ketimpangan. Hasil ini juga sesuai dengan penelitian terdahulu yang dilakukan oleh Turnovsky (2015) yang dalam penelitiannya menyimpulkan bahwa belanja pemerintah untuk modal publik akan meningkatkan ketimpangan kesejahteraan dari waktu ke waktu. Turnovsky berpendapat bahwa investasi pemerintah cenderung meningkatkan produktivitas modal swasta yang pada akhirnya terjadi ketimpangan distribusi hasil yang tidak merata antara pemilik dengan para buruh.

Hasil penelitian ini juga sesuai dengan penelitian Sabir (2015) dengan studi kasus di Provinsi Sulawesi Selatan yang menyimpulkan bahwa alokasi belanja modal pada APBD berpengaruh positif dan signifikan terhadap ketimpangan pendapatan. Artinya bahwa peningkatan belanja modal dalam APBD akan meningkatkan ketimpangan pendapatan masyarakat. Hal ini disebabkan karena alokasi belanja modal lebih banyak digunakan untuk pembangunan infrastruktur yang ada di daerah perkotaan dibandingkan alokasi di wilayah pedesaan.

Selain itu belanja infrastruktur yang ada mungkin tidak banyak berpengaruh terhadap peningkatan pendapatan masyarakat kalangan bawah khususnya para petani sehingga 
pertumbuhan ekonomi sebagian besar hanya dinikmati oleh para pelaku di sektor modern dan secara tidak langsung akan lebih menguntungkan para pengusaha dan pemilik modal besar. Untuk meningkatkan peran belanja infrastruktur dalam pemerataan pendapatan masyarakat, pemerintah daerah perlu meningkatkan efektivitas pelaksanaan belanja infrastruktur sehingga diperoleh manfaat yang lebih besar dalam peningkatan pendapatan masyarakat. Selain itu pemerintah daerah juga perlu memperhatikan sebaran pembangunan yang lebih meluas agar dapat memberikan dampak positif bagi kegiatan ekonomi masyarakat sampai daerah pinggiran. Dengan demikian diharapkan perekonomian masyarakat pinggiran dapat lebih sejahtera sehingga ketimpangan dengan masyarakat perkotaan dapat berkurang.

\subsubsection{Pengaruh PDRB Sektor Pertanian Terhadap Ketimpangan}

Hasil regresi untuk variabel rasio PDRB sektor pertanian terhadap total PDRB dalam penelitian ini menghasilkan output berpengaruh negatif dan tidak signifikan terhadap ketimpangan. Artinya perubahan besaran dari variabel ini tidak banyak berpengaruh terhadap kondisi ketimpangan yang ada. Lemahnya pengaruh perkembangan PDRB sektor pertanian terhadap ketimpangan kemungkinan besar dikarenakan kecinya nilai tambah yang dihasilkan para petani atas hasil pertaniannya. Hasil pertanian yang sebagian besar dijual berupa bahan mentah menghasilkan nilai tambah yang tidak sebesar apabila sudah melalui proses pengolahan. Selain itu keuntungan lebih tinggi mungkin didapat oleh para pedagang dan pengepul hasil pertanian sehingga bagian keuntungan yang menjadi hak para petani akan berkurang.

Kontribusi sektor pertanian yang semakin menurun dari tahun ke tahun juga mengakibatkan dampak sektor pertanian tidak dapat secara signifikan menurunkan ketimpangan. Menurunnya kontribusi sektor pertanian kemungkinan disebabkan oleh semakin menyempitnya lahan pertanian akibat alih fungsi lahan pertanian menjadi lahan non pertanian. Berdasarkan data BPS, luas lahan pertanian di Jawa Timur seluas 1.107.276 hektar pada tahun 2010. Luas lahan tersebut turun menjadi 1.091.752 hektar pada tahun 2015 atau turun sebanyak 15.524 hektar yang merupakan akibat dari alih fungsi lahan pertanian menjadi lahan permukiman, industri, dan sebagainya. Selain itu terdapat pula penurunan jumlah pekerja di sektor pertanian yang mempengaruhi hasil pertanian dimana pada tahun 2010 jumlah pekerja sektor pertanian sebanyak 7.939.480 jiwa dan pada tahun 2015 turun menjadi 7.083.252 jiwa atau turun sebesar 10,78\% dibanding tahun 2010 (BPS Provinsi Jawa Timur, 2016).

Hasil ini mendukung pendapat Kuznets bahwa akan terjadi pergeseran struktur ekonomi dimana peran perekonomian tradisional seperti sektor pertanian akan menurun dan bergeser ke sektor modern. Hasil ini juga mendukung Teori Penyebab Kumulatif yang dicetuskan Profesor Gunnar Myrdal yang menyatakan terjadinya migrasi tenaga kerja, modal, dan perdagangan ke daerah yang memberikan harapan laba yang lebih tinggi. Dalam kasus ini, wilayah dengan basis sektor pertanian menjadi daerah dengan harapan laba yang lebih rendah.

Untuk meningkatkan produktivitas pertanian dapa dilakukan dengan penggunaan teknologi. Seperti tercantum dalam Model Solow, teknologi dapat meningkatkan produktivitas pada saat penambahan modal dan tenaga kerja tak lagi memberikan peningkatan yang diharapkan. Kehadiran teknologi dalam kegiatan pertanian diharapkan juga dapat menekan biaya produksi sehingga keuntungan yang dihasilkan dapat lebih tinggi sehingga dapat mendukung usaha pemerataan kesejahteraan khususnya melalui penigkatan pendapatan para petani.

\subsubsection{Pengaruh PDRB Sektor Industri Terhadap Ketimpangan}

Hasil regresi untuk variabel rasio PDRB sektor industri dalam penelitian ini menghasilkan output berpengaruh negatif dan signifikan terhadap ketimpangan. Artinya perubahan besaran dari variabel ini cukup berpengaruh terhadap kondisi ketimpangan yang ada. Semakin besar rasio PDRB sektor industri terhadap total PDRB akan memberikan dampak pada penurunan tingkat ketimpangan pendapatan masyarakat.

Peningkatan PDRB sektor industri akan dapat menurunkan tingkat ketimpangan apabila menghasilkan rasio terhadap PDRB yang lebih besar dari sebelumnya. Artinya apabila persentase kenaikan PDRB sektor industri melebihi persentase kenaikan PDRB pada tahun yang sama maka akan dapat menurunkan ketimpangan pendapatan. Dengan kata lain bahwa peningkatan peran atau kontribusi sektor industri dalam perekonomian akan dapat mengurangi ketimpangan pendapatan masyarakat. Hasil dari penelitian ini mengindikasikan bahwa peningkatan rasio PDRB sektor industri memiliki dampak yang baik terhadap pemerataan ekonomi.

Peran sektor industri yang dapat menurunkan ketimpangan dapat terjadi karena tidak selamanya tingkat pengembalian mayoritas menjadi milik pemilik modal. Sektor industri di Jawa Timur memiliki karakteristik padat karya sehingga dapat menyerap banyak tenaga kerja dan memberi para 
pekerja penghasilan yang lebih layak, dengan perbedaan tingkat penghasilan yang tidak terlalu timpang dibandingkan sektor lainnya. Hal ini tercermin dari jumlah tenaga kerja yang terserap di sektor ini. Dengan perkembangan kontribusi terhadap PDRB yang relatif stabil, sektor industri mampu menyerap tenaga kerja tambahan sebanyak 217.113 jiwa selama tahun 2010-2015 atau naik sebesar $8,75 \%$, dari yang awalnya sebanyak 2.482.563 jiwa pekerja di tahun 2010 menjadi 2.699.676 jiwa pekerja di tahun 2015 (BPS Provinsi Jawa Timur, 2016).

Hasil ini mendukung pendapat Kuznets bahwa akan terjadi pergeseran struktur ekonomi dimana peran perekonomian tradisional akan menurun dan bergeser ke sektor modern seperti sektor industri. Melihat hasil penelitian ini dan juga perkembangan penyerapan tenaga kerja sektor industri di Jawa Timur, maka dapat dilihat bahwa sektor industri mampu menyerap tenaga kerja cukup tinggi dan perkembangan sektor industri pada akhirnya akan mengurangi ketimpangan pendapatan di Jawa Timur.

Hasil ini juga mendukung Teori Penyebab Kumulatif yang dicetuskan Profesor Gunnar Myrdal yang menyatakan terjadinya migrasi tenaga kerja, modal, dan perdagangan ke daerah yang memberikan harapan laba yang lebih tinggi. Dalam kasus ini, wilayah dengan basis sektor industri menjadi salah satu daerah yang memberikan harapan laba tinggi. Alih fungsi lahan pertanian merupakan cerminan pergeseran modal yang diantaranya digunakan untuk keperluan sektor industri. Bergitu pun penurunan tenaga kerja di sektor pertanian yang kontras dengan peningkatan tenaga kerja di sektor industri juga menjadi indikasi migrasi tenaga kerja. Perdagangan hasil pertanian pun menjadi pasokan komoditas bahan baku intuk sektor industri.

Berdasarkan penjabaran di atas, pengembangan sektor industri yang bersifat padat karya patut untuk digalakkan karena terbukti akan menurunkan ketimpangan pendapatan. Kebijakan pemerintah dalam mendorong sektor industri secara tidak langsung akan menurunkan ketimpangan pendapatan.

\subsubsection{Pengaruh PDRB Sektor Perdagangan Terhadap Ketimpangan}

Hasil regresi untuk variabel rasio PDRB sektor perdagangan dalam penelitian ini menghasilkan output berpengaruh positif dan signifikan terhadap ketimpangan. Artinya bahwa semakin besar rasio PDRB sektor perdagangan terhadap total PDRB akan memberikan dampak pada naiknya tingkat ketimpangan pendapatan masyarakat sehingga dapat menghambat pemerataan pendapatan.
Peningkatan PDRB sektor perdagangan akan dapat menaikkan tingkat ketimpangan apabila menghasilkan rasio terhadap PDRB yang lebih besar dari sebelumnya. Artinya apabila persentase kenaikan PDRB sektor perdagangan melebihi persentase kenaikan total PDRB pada tahun yang sama maka akan dapat mendorong naiknya ketimpangan pendapatan. Dampak positif PDRB sektor perdagangan terhadap ketimpangan pendapatan kemungkinan disebabkan oleh keuntungan yang lebih besar yang didapatkan para pedagang, yang sekaligus dapat mengurangi keuntungan bagi para penghasil barang yang diperdagangkan seperti misalnya hasil pertanian, peternakan, dan perikanan sehingga memperlebar ketimpangan antara para pelaku usaha di sektor perdagangan dengan sektor primer khususnya pertanian. Selain itu terdapat indikasi adanya upah yang rendah bagi para pekerja di sektor perdagangan yang cukup timpang dengan keuntungan yang diperoleh oleh para pemilik modal sehingga perkembangan sektor perdagangan tidak setara dengan peningkatan kesejahteraan para pekerjanya.

Hasil ini juga mendukung Teori Penyebab Kumulatif yang menyatakan terjadinya migrasi perdagangan ke daerah yang memberikan harapan laba yang lebih tinggi. Dalam kasus ini, wilayah dengan basis sektor perdagangan menjadi salah satu daerah yang memberikan harapan laba tinggi. Aktivitas perdagangan dapat menghasilkan laba yang lebih tinggi daripada sektor pertanian terutama sebagai pemasaran hasil sektor pertanian dan pemasaran hasil sektor industri, sekaligus penyalur perdagangan hasil pertanian sebagai pasokan komoditas bahan baku intuk sektor industri.

Untuk mengurangi dampak negatif sektor perdagangan terhadap pemerataan pendapatan, dibutuhkan peran pemerintah untuk melindungi produsen mauoun konsumen. Hal ini dapat dilakukan dengan penetapan harga terendah untuk menjamin penghasilan produsen, dan penetapan harga tertinggi sebagai wujud perlindungan konsumen.

\section{KESIMPULAN DAN SARAN}

Belanja modal K/L berpengaruh negatif dan signifikan terhadap ketimpangan di Jawa Timur. Artinya penambahan belanja modal K/L dapat memberikan dampak pada penurunan tingkat ketimpangan pendapatan apabila kenaikannya melebihi tingkat perubahan PDRB pada tahun yang sama. Hal ini mengindikasikan bahwa belanja modal K/L cukup efektif dalam mendukung pemerataan pendapatan masyarakat.

Belanja modal APBD berpengaruh positif dan signifikan terhadap ketimpangan di Jawa Timur. 
Artinya penambahan belanja modal APBD dapat memberikan dampak pada naiknya tingkat ketimpangan pendapatan apabila kenaikannya melebihi tingkat perubahan PDRB pada tahun yang sama. Hal ini mengindikasikan bahwa belanja modal APBD belum efektif dalam mendukung pemerataan pendapatan masyarakat.

PDRB sektor pertanian berpengaruh negatif dan tidak signifikan terhadap ketimpangan. Artinya perkembangan sektor pertanian tidak banyak berpengaruh terhadap kondisi ketimpangan yang ada. Hal ini disebabkan oleh kecinya nilai tambah yang dihasilkan dari hasil pertanian dan juga akibat penurunan kontribusi sektor pertanian karena alih fungsi lahan pertanian dan penurunan jumlah tenaga kerja di sektor pertanian.

PDRB sektor industri berpengaruh negatif dan signifikan terhadap ketimpangan. Artinya perkembangan sektor industri dapat menurunkan ketimpangan pendapatan di Jawa Timur. Hal ini disebabkan oleh karakteristik sektor industri yang bersifat padat karya sehingga dapat menyerap banyak tenaga kerja dan memberi para pekerja penghasilan yang lebih layak dengan adanya upah minimum regional.

PDRB sektor perdagangan berpengaruh positif dan signifikan terhadap ketimpangan. Artinya perkembangan sektor perdagangan dapat meningkatkan ketimpangan pendapatan di Jawa Timur. Hal ini disebabkan oleh distribusi keuntungan yang lebih besar untuk pedagang yang akan mengurangi keuntungan bagi para penghasil barang yang diperdagangkan terutama dari sektor pertanian.

Dari pembahasan dan kesimpulan maka dapat penulis sampaikan beberapa saran sebagai berikut. Pemerintah dapat menjadikan variabel rasio belanja modal K/L dan rasio belanja modal APBD sebagai pertimbangan dalam pembuatan kebijakan anggaran. Penggunaan variabel rasio dapat menjadi alternatif perhitungan matematis dalam perumusan kebijakan khususnya pada kebijakan alokasi belanja modal dan kebijakan-kebijakan dalam sektor ekonomi yang berdampak pada pemerapataan pendapatan masyarakat.

Peningkatan efektivitas pelaksanaan anggaran perlu ditingkatkan khususnya pada belanja modal APBD agar dapat turut berperan dalam penurunan ketimpagan pendapatan. Pemerintah daerah perlu meningkatkan efektivitas pelaksanaan belanja infrastruktur dan memperluas pembangunan hingga ke pelosok daerah agar dampak dari belanja infrastruktur dapat lebih berperan dalam peningkatan pendapatan masyarakat pinggiran.

Pemerintah daerah yang memiliki PDRB tinggi seperti Kota Surabaya, Kota Malang, Kota Kediri, Kabupaten Gresik, dan Kabupaten Sidoarjo seharusnya mulai mengalihkan perhatiannya pada pemerataan pendapatan sehingga kesejahteraan dapat dinikmati oleh masyarakat luas. PDRB yang tinggi mencerminkan pembangunan pertumbuhan dan tingkat perekonomian yang tinggi dari wilayah-wilayah tersebut. Di sisi lain pertumbuhan ekonomi tersebut belum diimbangi dengan pemerataan pendapatan sehingga prioritas pembangunan seharusnya bergeser ke pemerataan pendapatan.

Dukungan belanja modal infrastruktur sangat diperlukan baik dari Pemerintah Provinsi maupun Pemerintah Pusat untuk mendorong pembangunan ekonomi pada Kabupaten Pamekasan, Kabupaten Situbondo, Kabupaten Sampang, Kabupaten Bondowoso, Kabupaten Ngawi, Kabupaten Bangkalan, dan Kabupaten Madiun. Kabupatenkabupaten tersebut memiliki pertumbuhan ekonomi dan tingkat PDRB serta tingkat pemerataan pendapatan yang masih rendah sehingga memerlukan perhatian lebih dari pemerintah.

Penerapan teknologi pertanian sudah selayaknya dilakukan untuk mendorong produktivitas sekaligus menekan biaya produksi sehingga keuntungan para petani menjadi lebih tinggi. Peran pemerintah juga diperlukan untuk mendorong perkembangan sektor industri yang bersifat padat karya karena terbukti dapat menurunkan ketimpangan. Peran pemerintah dalam sektor perdagangan diperlukan untuk mengurangi dampak negatif sektor perdagangan terhadap pemerataan pendapatan, misalnya dengan penetapan harga terendah untuk menjamin penghasilan produsen, dan penetapan harga tertinggi sebagai wujud perlindungan konsumen.

\section{IMPLIKASI DAN KETERBATASAN}

Penelitian ini memberikan alternatif pengukuran yang didasarkan pada rasio atau perbandingan variabel bebas dengan output perekonomian. Penelitian ini membuahkan perspektif bahwa ukuran rasio dapat dijadikan alternatif kebijakan yang memberikan hasil berbeda dengan ukuran angka mutlak. Tidak selamanya perubahan besaran variabel mutlak akan berdampak sama dengan variabel rasio terhadap PDRB.

Penelitian ini belum dapat menjelaskan secara ilmiah penyebab variabel-variabel bebas berpengaruh sedemikian rupa terhadap variabel terikat. Oleh karena itu diperlukan penelitian lanjutan untuk mengetahui karakteristik masingmasing variabel sehingga dapat mendukung kebijakan yang lebih tajam pada permasalahan utama.

PENGHARGAAN (ACKNOWLEDGEMENT) 
Ucapan terima kasih penulis sampaikan kepada para pihak yang telah memberikan kontribusi berupa sumbang saran dan kontribusi lainnya terhadap penyelesaian Karya Tulis Ilmiah ini. Penulis juga bertanggung jawab sepenuhnya terhadap hasil penelitian termasuk error yang kemungkinan terjadi.

\section{DAFTAR PUSTAKA (REFERENCES)}

Badan Pusat Statistik. 2017. [Seri 2010] Distribusi PDRB Terhadap Jumlah PDRB 34 Provinsi Atas Dasar Harga Berlaku Menurut Provinsi, 2010-2016 (Persen). (https://www.bps.go.id/dynamictable/2015/ 10/07/959/-seri-2010-distribusi-pdrbterhadap-jumlah-pdrb-34-provinsi-atasdasar-harga-berlaku-menurut-provinsi-20102016-persen-.html) diakses pada tanggal 9 Februari 2018.

_.2018. Gini Ratio Provinsi 2002-2017. (https://www.bps.go.id/dynamictable/2017/ 04/26/1116/gini-ratio-provinsi-20022017.html) diakses pada tanggal 9 Februari 2018.

_.2018. Laju Pertumbuhan PDRB ADH Konstan Menurut Pengeluaran. Tabel Dinamis. diakses pada tanggal 9 Februari 2018.

_.2018. PDRB ADH Berlaku Menurut Pengeluaran. Tabel Dinamis. diakses pada tanggal 9 Februari 2018.

Badan Pusat Statistik Provinsi Jawa Timur. 2015. Produk Domestik Regional Bruto Kabupaten/Kota Menurut Lapangan Usaha 2010-2014.

_.2016. Gini Rasio Jawa Timur 2008 - 2015. (https://jatim.bps.go.id/dynamictable/2016/ 10/13/10/gini-rasio-jawa-timur-2008--2015.html) diakses pada tanggal 9 Februari 2018.

_.2016. Penduduk Berumur 15 Tahun ke Atas yang Bekerja Menurut Kabupaten/Kota dan Lapangan Pekerjaan Utama Tahun 2005 2015.

(https://jatim.bps.go.id/statictable/2016/10/ 12/358/penduduk-berumur-15-tahun-keatas-yang-bekerja-menurut-kabupaten-kotadan-lapangan-pekerjaan-utama-tahun-2005--2015.html) diakses pada tanggal 17 April 2018.

_.2017. Distribusi PDRB Provinsi Jawa Timur Atas Dasar Harga Berlaku Menurut Lapangan Usaha Tahun 2010-2016. (https://jatim.bps.go.id/dynamictable/2017/ 07/05/36/distribusi-pdrb-provinsi-jawatimur-atas-dasar-harga-berlaku-menurut- lapangan-usaha-tahun-2010-2016-persen.html) diakses pada tanggal 9 Februari 2018.

.2017. PDRB Provinsi Jawa Timur Atas Dasar Harga Berlaku Menurut Lapangan Usaha Tahun 2010-2016. (https://jatim.bps.go.id/dynamictable/2017/ 07/05/34/pdrb-provinsi-jawa-timur-atasdasar-harga-berlaku-menurut-lapanganusaha-tahun-2010-2016-milyar-rupiah-.html) diakses pada tanggal 9 Februari 2018.

.2017. Produk Domestik Regional Bruto Provinsi Jawa Timur Kabupaten/Kota Menurut Lapangan Usaha 2012-2016.

.2018. Distribusi PDRB Atas Dasar Harga Berlaku Terhadap PDRB 38 Kabupaten/Kota di Jawa Timur, 2010-2016. (https://jatim.bps.go.id/dynamictable/2018/ 01/16/207/distribusi-pdrb-atas-dasar-hargaberlaku-terhadap-pdrb-38-kabupaten-kotadi-jawa-timur-2010-2016.html) diakses pada tanggal 9 Februari 2018.

_.2018. PDRB Atas Dasar Harga Berlaku Menurut Kabupaten/Kota di Jawa Timur, 2010-2016. (https://jatim.bps.go.id/dynamictable/2018/ 01/16/223/pdrb-atas-dasar-harga-berlakumenurut-kabupaten-kota-di-jawa-timur2010-2016.html) diakses pada tanggal 9 Februari 2018.

.2018. PDRB Perkapita Atas Dasar Harga Berlaku Menurut Kabupaten/Kota di Jawa Timur, 2010-2016.

(https://jatim.bps.go.id/dynamictable/2018/ 01/16/221/pdrb-perkapita-atas-dasar-hargaberlaku-menurut-kabupaten-kota-di-jawatimur-2010-2016.html) diakses pada tanggal 9 Februari 2018.

Direktorat Jenderal Perimbangan Keuangan. 2017. Data Keuangan Daerah Setelah 2006. (http://www.djpk.kemenkeu.go.id/?p=5412) diakses pada tanggal 4 Februari 2018.

Gujarati, D. N., Dawn C. Porter. 2008. Basic Econometrics. McGraw-Hill/Irwin - USA

Hakim, Lukman. 2014. Pengaruh Belanja Modal Terhadap Pertumbuhan Ekonomi: Studi Kasus Kabupaten dan Kota di Pulau Jawa dan Bali. Skripsi. Universitas Brawijaya: Malang. In-text reference: (Hakim, 2014)

Hur, Seok-Kyun. 2014. Government Spending and Inclusive Growth in Developing Asia. ADB Economics Working Paper Series No. 415, PP 1-39.

(https://www.adb.org/sites/default/files/pu blication/149219/ewp-415.pdf) diakses pada tanggal 5 Februari 2018.

In-text reference: (Hur, 2014) 
Ivanic, Maros, Will Martin. 2017. Sectoral Productivity Growth and Poverty Reduction: National and Global Impacts. World Development.

(http://doi.org/10.1016/j.worlddev.2017.07. 004) diakses pada tanggal 18 Februari 2018.

In-text reference: (Ivanic, 2017)

Jhingan, M.L. 2016. Ekonomi Pembangunan dan Perencanaan. Rajawali Pers: Jakarta.

In-text reference: (Jhingan, 2016)

Kuznets, S. 1955. Economic Growth and Income Inequality. The American Economic Review, Vol. 45, No.1,PP 1-28. (http://www.jstor.org/stable/1811581)

diakses tanggal 5 Februari 2018.

In-text reference: (Kuznets, 1955)

López, J. 2010. Pro-growth, pro-poor: Is there a trade-off. The World Bank (PRMPR). (http://siteresources.worldbank.org/INTPGI/ Resources/15040_WBSWP3378.pdf) diakses pada tanggal 5 Februari 2018.

In-text reference: (López, 2010)

Mankiw, N. Gregory. 2007. Makroekonomi: Edisi Keenam. Penerbit Erlangga: Jakarta.

In-text reference: (Mankiw, 2007)

Okun, A. M. 1975. Equality and Efficiency: The Big Tradeoff.

https://assets.aspeninstitute.org/content/upl oads/files/content/docs/OKUN_EQUALITY_A ND_EFFICIENCY_(AS08).PDF) diakses pada tanggal 5 Februari 2018.

In-text reference: (Okun, 1975)

Rubin, A., \& Segal, D. 2015. The effects of economic growth on income inequality in the US. Journal of Macroeconomics, Vol. 45, PP 258273.

(https://doi.org/10.1016/j.jmacro.2015.05.0

07) diakses pada tanggal 5 Februari 2018.

In-text reference: (Rubin \& Segal, 2015)

Sabir, Yustika, A. E., Susilo, \& Maskie, G. 2015. Local Government Expenditure, Economic Growth and Income Inequality in South Sulawesi Province. Journal of Applied Economics and Business Vol. 3, Ed. 2, PP 61-73. (http://www.aebjournal.org/articles/0302/0 30205.pdf) diakses tanggal 3 Februari 2018.

In-text reference: (Sabir, 2015)

Shin, I. 2012. Income inequality and economic growth. Economic Modelling, Vol. 29, Ed. 5, PP 2049-2057.

(https://doi.org/10.1016/j.econmod.2012.02. 011) diakses pada tanggal 5 Februari 2018.

In-text reference: (Shin, 2012)

Todaro, Michael P., Stephen C. Smith. 2012. Economic Development 11th Ed. Pearson Higher Ed. USA.
In-text reference: (Todaro, 2012)

Turnovsky, S. J. 2015. Economic growth and inequality: The role of public investment. Journal of Economic Dynamics and Control, Vol. 61, PP 204-221. (https://doi.org/10.1016/j.jedc.2015.09.009) diakses pada tanggal 9 Februari 2018.

In-text reference: (Turnovsky, 2015)

Undang-Undang Nomor 17 Tahun 2003 Tentang Keuangan Negara.

Undang-Undang Nomor 23 Tahun 2014 tentang Pemerintah Daerah.

Utama, Zamrud Siswa. 2017. Pengaruh Kebijakan Fiskal pada Pertumbuhan dan Ketimpangan Ekonomi Indonesia: Studi Kasus 1980-2015. Tesis. Universitas Brawijaya: Malang.

In-text reference: (Utama, 2017). 